\title{
AWARENESS ABOUT BIOMEDICAL WASTE MANAGEMENT AMONGST MEDICAL INTERNS- AN INTERVENTIONAL STUDY FROM CENTRAL INDIA
}

\author{
Anasua Deb ${ }^{1}$, Sunita Gajbhiye2, Sharmila Raut ${ }^{3}$ \\ ${ }^{1}$ Assistant Professor, Department of Microbiology, Indira Gandhi Government Medical College and Mayo Hospital, Nagpur, India. \\ ${ }^{2}$ Assistant Professor, Department of Microbiology, Indira Gandhi Government Medical College and Mayo Hospital, Nagpur, India. \\ 3Professor \& HOD, Department of Microbiology, Indira Gandhi Government Medical College and Mayo Hospital, Nagpur, India.
}

\section{ABSTRACT}

\section{BACKGROUND}

Biomedical waste (BMW) management policies are mandated in hospitals to reduce the risks of health hazards from the hospital waste. Strict adherence to the norms requires a teamwork from healthcare workers including doctors, nursing staff, attendants as well as medical interns and residents.

\section{MATERIALS AND METHODS}

In this study, we evaluated the baseline knowledge of medical interns about BMW management using a structured questionnaire and devised a scoring system based on the response. The interns were then inducted with a series of didactic lectures along with practical demonstrations periodically over a period of 3 months.

\section{RESULTS}

At the end of this interventional training, medical interns were reassessed using the same questionnaire. Knowledge on all parameters was markedly improved at post-course evaluation of the participants. Significant improvement in the overall score was achieved $(\mathrm{p}<0.05)$.

\section{CONCLUSION}

Management of BMW is a team-work and medical interns are an essential part of the healthcare team. There were several lacunae in the knowledge about hospital waste management amongst medical interns which subsequently improved with our training interventions. We recommend regular vocational activities by the hospital infection control committee in order to successfully implement the BMW management rules in the hospital. In addition, constant vigilance on the BMW disposal should be integrated in the infection control activities in the hospital.

\section{KEYWORDS}

Biomedical Waste (BMW), Awareness, Knowledge.

HOW TO CITE THIS ARTICLE: Deb A, Gajbhiye S, Raut S. Awareness about biomedical waste management amongst medical interns- An interventional study from Central India. J. Evolution Med. Dent. Sci. 2017;6(16):1256-1259, DOI: $10.14260 /$ Jemds/2017/273

\section{BACKGROUND \\ Waste generated during the diagnosis, treatment or immunisation of human beings or animals or in research activities is defined as biomedical waste which are potentially hazardous to the individuals working with them as well as to the community at large. Such wastes produced in the course of healthcare activities can act as a source of infection and injury to the exposed person and can also have a significant impact on the environment. Persons at risk of exposure include healthcare professionals (Doctors, nurses, and attendants, support personnel for waste handling, transportation and laundry), patients and their visitors, employees at the waste management facilities and scavengers. It is estimated that in India approximately 0.5 to}

Financial or Other, Competing Interest: None.

Submission 16-01-2017, Peer Review 08-02-2017,

Acceptance 15-02-2017, Published 23-02-2017.

Corresponding Author:

Dr. Anasua Deb,

Assistant Professor

Department of Microbiology,

Indira Gandhi Government Medical College and

Mayo Hospital, Nagpur, India.

E-mail: anasua.deb@gmail.com

DOI: $10.14260 /$ jemds $/ 2017 / 273$
$2.0 \mathrm{~kg}$ of BMW per bed is generated in a day, which cumulates to about 0.33 million tons of hospital waste annually. ${ }^{1}$ The Ministry of Environment and Forestry has laid down guidelines and regulations for management and handling of biomedical wastes (BMW) in Schedule I of BMW Rules of $1998^{2}$ which was subsequently amended in 2011 and in 2016.3,4

The awareness among health care professionals regarding the hazards of BMW and necessary management strategies is increasing globally; however, India is lagging far behind.5,6,7 The condition in developing countries and particularly in India is critical due to the insufficient financial and human resources, lack of awareness about the health hazards of BMW, poor adherence to the proper waste disposal and management policies. ${ }^{8}$ Adequate knowledge about the health hazards of BMW and their proper techniques of handling and disposal, including practice of necessary safety measures, can help to prevent the various adverse effects of the hazardous waste. With this background, present study was conducted to assess the awareness and knowledge of medical interns regarding BMW management in our hospital.

Several studies have assessed the knowledge and practice of BMW management in healthcare professionals in India as well as worldwide; however, none has addressed the 
awareness and knowledge in medical interns. Medical interns are an important class of healthcare professionals who are naïve with regards to the BMW management policies and are thus vulnerable to the hazards. Moreover, in a high burden tertiary care set-up like ours, interns have to necessarily participate in patient care including invasive procedures and thus come in direct contact with various sources of BMW. It is therefore necessary that they remain updated about the current guidelines and policies for handling BMW. The infection control committee of the hospital carries out regular vocational training activities keeping this in mind.

\section{MATERIALS AND METHODS}

The study was carried out in Indira Gandhi government Medical College and Mayo hospital, Nagpur, which is a tertiary care teaching hospital in central India. The study was done over a 3-month period (March - May 2016) as a part of routine vocational and training activity carried out under the auspices of the infection control committee of the hospital. Participants included medical interns working in different departments of the hospitals like paediatric, medical and surgical wards, intensive care units, casualty/emergency unit, burns wards, operation theatres and labour rooms. A total of 140 medical interns consented for participation in the study after they were briefed about the purpose and nature of the study. Their knowledge and awareness about BMW management was assessed using a predesigned pretested structured questionnaire and a Scoring system was devised giving equal weightage to all the questions. Anonymity of the participants was maintained throughout the study.

Following this, an interventional strategy was implemented in the form of a series of didactic lectures using Power Point Presentations including practical demonstration of BMW disposal regularly over a period of 3 months. At the end of this inductive training, the interns were reassessed about their knowledge on BMW management using the same questionnaire. For assessment of the response to the questions, the guidelines drafted by the Ministry of Health and Family Welfare, Government of India (REF) was used as the reference standard.

Data was analysed using Microsoft Excel software and percentages, proportions and p-values were calculated (Student's paired t-test). A p-value $<0.05$ was considered statistically significant.

\section{RESULTS}

A total of 140 medical interns participated in the study of which 76(54.3\%) were male and 64(45.7\%) were female. The mean age of the interns was $24 \pm 2.63$ years. The response rate was $100 \%$. We also found that $88.6 \%$ (124/140) were vaccinated for Hepatitis B and $100 \%$ for tetanus. However, 6 interns reported that the last booster dose for TT was taken more than 3 years back.

The interns were evaluated using the same questionnaire before and after the training activities. The pre- and posttraining assessment responses have been tabulated in the table 1 below.

\begin{tabular}{|c|c|c|}
\hline $\begin{array}{c}\text { Questions Regarding } \\
\text { Knowledge on Biomedical } \\
\text { Waste Management }\end{array}$ & $\begin{array}{c}\text { Pre- } \\
\text { Training } \\
\text { Correct } \\
\text { Response } \\
\text { N (\%) }\end{array}$ & $\begin{array}{c}\text { Post- } \\
\text { Training } \\
\text { Correct } \\
\text { Response } \\
\text { N (\%) }\end{array}$ \\
\hline \multicolumn{3}{|c|}{ I. Knowledge about BMW Management Rule } \\
\hline $\begin{array}{l}\text { Awareness about } \\
\text { Existence of Rule? }\end{array}$ & $119(85)$ & $140(100)$ \\
\hline Year of Latest Amendment? & $26(18.6)$ & $125(89.3)$ \\
\hline $\begin{array}{l}\text { Is improper Handling a } \\
\text { Punishable Offense? }\end{array}$ & $67(47.8)$ & $136(97.1)$ \\
\hline $\begin{array}{c}\text { Who Laid Down the } \\
\text { Rules for BMW Handling? }\end{array}$ & $41(29.3)$ & $103(73.6)$ \\
\hline \multicolumn{3}{|c|}{ II. Generation of Biomedical Waste } \\
\hline $\begin{array}{l}\text { Recognise the } \\
\text { Symbol of BMW? }\end{array}$ & $102(72.8)$ & $139(99.3)$ \\
\hline Generated by? & $98(70)$ & $133(95)$ \\
\hline Site of Generation? & $106(75.7)$ & $140(100)$ \\
\hline $\begin{array}{l}\text { Number of Containers to } \\
\text { be Kept at Such Site? }\end{array}$ & $133(95)$ & $139(99.3)$ \\
\hline \multicolumn{3}{|l|}{ III. Segregation of BMW } \\
\hline $\begin{array}{l}\text { Where Segregation should be } \\
\text { Done? }\end{array}$ & $25(17.8)$ & $135(96.4)$ \\
\hline $\begin{array}{c}\text { Segregation is } \\
\text { Responsibility of? }\end{array}$ & $26(18.6)$ & $124(88.6)$ \\
\hline $\begin{array}{l}\text { Number of Classes } \\
\text { of Segregation? }\end{array}$ & $47(33.6)$ & $136(97.1)$ \\
\hline Colour Coding Existent? & $133(95)$ & $140(100)$ \\
\hline Number of Colour Codes? & $123(87.8)$ & $140(100)$ \\
\hline Disinfection Necessary? & $103(73.6)$ & $126(90)$ \\
\hline $\begin{array}{l}\text { Which Class of BMW } \\
\text { Should be Disinfected? }\end{array}$ & $35(25)$ & $125(89.3)$ \\
\hline How is Disinfection Done? & $11(7.8)$ & $127(90.7)$ \\
\hline How are Sharps Disposed? & $38(27.1)$ & $129(92.1)$ \\
\hline How are Needles Disposed? & $33(23.6)$ & $130(92.8)$ \\
\hline Filling of Waste Bags? & $32(22.8)$ & $129(92.1)$ \\
\hline \multicolumn{3}{|l|}{ IV. Health hazards of BMW } \\
\hline Is BMW Hazardous? & $136(97.1)$ & $140(100)$ \\
\hline $\begin{array}{c}\text { Proportion of Hazardous } \\
\text { Waste Amongst total Hospital } \\
\text { Waste Generated? }\end{array}$ & $38(27.1)$ & $97(69.3)$ \\
\hline Diseases Spread from BMW? & $113(80.7)$ & $126(90)$ \\
\hline Person at Risk of Exposure? & $95(67.8)$ & $133(95)$ \\
\hline $\begin{array}{l}\text { Personal Protective Equipment } \\
\text { Necessary? }\end{array}$ & $106(75.7)$ & $139(99.3)$ \\
\hline $\begin{array}{l}\text { What Vaccination to } \\
\text { be Given? }\end{array}$ & $136(97.1)$ & $140(100)$ \\
\hline \multicolumn{3}{|l|}{ V. Disposal of BMW } \\
\hline Who Controls BMW Disposal? & $39(27.8)$ & $122(87.1)$ \\
\hline $\begin{array}{l}\text { Maximum Permissible } \\
\text { Time till which BMW } \\
\text { can be Stored in } \\
\text { the Hospital? }\end{array}$ & $42(30)$ & $84(60)$ \\
\hline Method of Final Disposal? & $69(49.3)$ & $125(89.3)$ \\
\hline $\begin{array}{l}\text { IGGMC has Own Disposal } \\
\text { Plant/Outsourced? }\end{array}$ & $75(53.6)$ & $132(94.3)$ \\
\hline $\begin{array}{l}\text { Name of Outsourcing } \\
\text { Company? }\end{array}$ & 0 & 36 (25.7) \\
\hline 3-R Rule Awareness? & $50(35.7)$ & $127(90.7)$ \\
\hline $\begin{array}{l}\text { Table 1. Correct } \\
\text { Participants before }\end{array}$ & $\begin{array}{l}\text { ponse ra } \\
\text { d after } T\end{array}$ & \\
\hline
\end{tabular}


Table 1 shows that there was improvement in knowledge in all the parameters. Most of the interns were also aware of colour coding system of BMW and the associated health hazards even before training. However, the baseline knowledge regarding the BMW management regulations, segregation and disposal of BMW was low. On post-training assessment, there was significant improvement in knowledge in these aspects $(\mathrm{p}<0.05)$. Table 2 shows the pre- and posttraining scores of the participants, which showed marked improvement after the training sessions. The increase in overall score was also statistically significant $(p<0.05)$ after our training intervention.

\begin{tabular}{|c|c|c|c|}
\hline $\begin{array}{l}\text { Assessment } \\
\text { Category }\end{array}$ & $\begin{array}{c}\text { Pre- } \\
\text { Training } \\
\text { Score } \\
\text { Mean } \pm \text { S.D. }\end{array}$ & $\begin{array}{l}\text { Post- } \\
\text { Training } \\
\text { Score } \\
\text { Mean } \pm \text { S.D. }\end{array}$ & $\begin{array}{c}\text { P- } \\
\text { value }\end{array}$ \\
\hline $\begin{array}{ll}\text { I. } & \text { Knowledge about } \\
\text { BMW } \\
\text { Management } \\
\text { Rule } \\
\end{array}$ & $1.07 \pm 2.32$ & $3.64 \pm 1.43$ & $<0.05$ \\
\hline $\begin{array}{l}\text { II. Generation of } \\
\text { Biomedical } \\
\text { Waste }\end{array}$ & $3.14 \pm 0.98$ & $3.94 \pm 0.08$ & $>0.05$ \\
\hline $\begin{array}{l}\text { III. Segregation of } \\
\text { BMW }\end{array}$ & $3.63 \pm 8.87$ & $10.34 \pm 4.35$ & $<0.05$ \\
\hline $\begin{array}{l}\text { IV. Health Hazards } \\
\text { of BMW }\end{array}$ & $4.46 \pm 3.32$ & $5.53 \pm 1.14$ & $>0.05$ \\
\hline V. Disposal of BMW & $1.96 \pm 5.22$ & $4.47 \pm 3.59$ & $<0.05$ \\
\hline VI. Overall Score & $14.26 \pm 10.19$ & $27.92 \pm 14.37$ & $<0.05$ \\
\hline \multicolumn{4}{|c|}{$\begin{array}{l}\text { Table 2. Pre- and Post-training } \\
\text { Scores of Study Participants }\end{array}$} \\
\hline
\end{tabular}

At the end of the training session, we also asked for feedback regarding the usefulness and necessity of the training activities. Majority (98\%) found the training was useful and 94\% (132/140) interns responded that they would like to participate in such future training activities.

\section{DISCUSSION}

Medical interns form an integral part of the health care community, especially in developing countries like India, where there is huge burden on healthcare and the shortage of manpower. The interns in our hospital, which is a tertiary care government teaching hospital, are involved in patient care and are thus exposed to the potential health hazards associated with biomedical wastes. It is therefore imperative that their knowledge and skill in the aspects of BMW handling and disposal should be up-to-date to prevent any possible health hazards resulting from mishandling of the BMW. We therefore assessed their knowledge and awareness in this subject as a part of routine training activities of the infection control committee of the hospital.

Although several studies have assessed the knowledge of healthcare professionals including doctors, resident doctors, nurses, laboratory technicians, attendants and support staff,5,6,7 none has addressed knowledge assessment of medical interns in their study. A few studies have assessed the knowledge in MBBS students.9,10 In most of the studies, it was observed that the knowledge about biomedical waste management was deficient amongst health care professionals. We also observed that the baseline knowledge was poor among medical interns in our study. The general awareness about the BMW and the health hazards associated with their improper handling was satisfactory as a result of the topic being incorporated in the undergraduate medical curriculum. However, we observed several knowledge gaps in the practical aspects of BMW handling and disposal which was addressed by repeated focused discussions, lectures and practical demonstrations. The post-training scores showed significant improvements in the aspects of segregation and disposal as well as BMW management regulations.

Continuous medical education is an important means to improve knowledge in healthcare professionals. Didactic lectures along with practical demonstrations is an important teaching and learning method which is logistically easy to implement in resource-limited settings. However, it is important that such training interventions should be implemented periodically on a regular basis in order to be effective rather than as a one-time endeavour. We, therefore, carried out continuous training activities with the interns and other health professional groups in the hospital over a period of 3 months. The post-training assessment results were then assessed which showed satisfactory improvement in knowledge amongst the study group, thus highlighting the effectiveness of such simple training interventions. We recommend periodical assessment of knowledge and focused training based on the observed knowledge gaps for long-term effectiveness of training interventions.

\section{CONCLUSION}

Management of BMW is a team-work and medical interns are an essential part of the healthcare team. There were several lacunae in the knowledge about hospital waste management amongst medical interns which subsequently improved with our training interventions. We recommend regular vocational activities by the hospital infection control committee in order to successfully implement the BMW management rules in the hospital. In addition, constant vigilance on the BMW disposal should be integrated in the infection control activities of the hospital.

\section{ACKNOWLEDGEMENT}

We acknowledge the Dean of Indira Gandhi Government Medical College and Mayo Hospital, Nagpur and the study participants.

\section{REFERENCES}

[1] Patil AD, Shekdar AV. Health-care waste management in India. J Environ Manage 2001;63(2):211-20.

[2] Bio-Medical Waste (Handling and Management) Rules 1998. Available from: http:// www. moef.nic.in/legis/hsm/biomed.html [Last accessed on 2016 Feb 14].

[3] Ministry of Environment and Forests. Government of India. Draft Bio-Medical Waste (Management and Handling) Rules, 2011. Available from: http://moef.nic.in/downloads/ public-information/ salient-features-draft-bmwmh.pdf, accessed on Feb 18, 2016.

[4] Ministry of Environment, Forests and climate change, Government of India. Draft Bio-Medical Waste (Management and Handling) Rules, 2016. Available from:

http://www.moef.nic.in/sites/default/files/Final_vett ed_BMW\%20Rules\%202015.pdf [Last accessed on 2016 May 20]. 


\section{Jemds.com}

[5] Bhagawati G, Nandwani S, Singhal S. Awareness and practices regarding bio-medical waste management among health care workers in a tertiary care hospital in Delhi. Indian J Med Microbiol 2015;33(4):580-2.

[6] Mathur V, Dwivedi S, Hassan M, et al. Knowledge, attitude, and practices about biomedical waste management among healthcare personnel: a crosssectional study. Indian J Comm Med 2011;36(2):143-5.

[7] Rao PH Hospital waste management system-a case study of a south Indian city. Waste Manag Res 2009;27(4):313-21.

\section{Original Research Article}

[8] INCLEN Program Evaluation Network (IPEN) study group. Bio-medical waste management: situational analysis \& predictors of performances in 25 districts across 20 Indian states. Indian $\mathrm{J}$ Med Res 2014;139(1):141-53.

[9] Makadia JS, Joshi A, Gohel MG. Importance of clinical posting for awareness on bio-medical waste in medical and paramedical students. International J Med Pub Health 2014;4(4):377-9.

[10] Jahnavi G, Raju PV. Awareness and training need of biomedical waste management among undergraduate students, Andhra Pradesh. Indian J Public Health 2006;50(1):53-4. 